\title{
Sociedade Civil e Globalização: Repensando Categorias*
}

\author{
Jean L. Cohen
}

\section{INTRODUÇÃO}

$\mathrm{O}$

discurso da sociedade civil "globalizou-se". Conceito muito usado atualmente por políticos, acadêmicos e ativistas em todo o mundo, o termo "sociedade civil" é invocado para tudo, designando desde empreendimentos cívicos, associações voluntárias e organizações sem fins lucrativos até redes mundiais, organizações não-governamentais, grupos de defesa dos direitos humanos e movimentos sociais transnacionais. Aliás, a idéia de uma sociedade civil mundial ou transnacional já se tornou a principal contribuição do século XXI ao debate sobre esse conceito. E assim como no passado, na maioria das vezes o discurso da sociedade civil trata-a como elemento essencial para a democracia e o processo de democratização e como a fonte principal da solidariedade e da integração social ${ }^{1}$. Entretanto, o contexto em que a discussão irrompeu já não é o do Estado, nem é este o alvo da democratização e da integração, mas a ordem mundial emergente.

\footnotetext{
* [A tradução do original em inglês "Civil Society and Globalization: Rethinking the Categories" é de Vera Pereira.]

DADOS - Revista de Ciências Sociais, Rio de Janeiro, Vol. 46, nํ3, 2003, pp. 419 a 459.
} 
O motivo dessa mudança de foco é óbvio: a percepção de que os processos de globalização tendem a solapar a capacidade dos Estados para o exercício das funções cruciais de controle e regulação da economia e da sociedade. Os Estados Nacionais parecem estar mais se amoldando aos imperativos da economia e do mercado do que os modelando. A globalização da economia, inclusive a vertiginosa expansão do comércio internacional, a rapidez dos fluxos de capitais, a crescente autonomização das redes financeiras e de circulação, o imenso poder das sociedades anônimas transnacionais, com base nas novas tecnologias eletrônicas de comunicação, tudo parece substituir "os governantes do território" pelos "mentores da velocidade" ${ }^{2}$.

Outros fatos associados com a globalização também tendem a diminuir a importância do Estado e, por conseqüência, a relevância da sociedade política nacional como um referente ou um foco de influência para os atores sociais. A natureza transnacional dos "riscos", em que se incluem os problemas ecológicos e ambientais (desde os acidentes nucleares à chuva ácida), as questões de saúde pública (como a Aids e a pneumonia asiática), as organizações criminosas internacionais ligadas ao tráfico de drogas, armas e sexo, a proliferação dos incidentes envolvendo imigrantes e refugiados políticos, o terrorismo em escala mundial e os planos militares e imperiais unilaterais, tudo isso acentua a vulnerabilidade e o baixo controle dos Estados nacionais modernos sobre seus territórios e fronteiras, sua população residente e os perigos com que se defrontam os cidadãos. Na verdade, a fronteira entre o nacional e o transnacional parece estar se diluindo, pondo em dúvida a soberania do Estado (ver Strange, 1996; Sassen, 1996; Cohen, 1999a).

Observa-se, por outro lado, a notável expansão não só de várias instituições supranacionais dedicadas à regulação e produção de regras, como o Fundo Monetário Internacional - FMI, o Banco Mundial, a Organização Mundial do Comércio - OMC e a União Européia, mas também de uma pletora de agências privadas de âmbito mundial, como associações que definem normas e padrões de comércio (Cutler, 2001; Rosenau, 1997; 1999; Teubner, 1996). A multiplicação de fontes do direito acima do nível do Estado e a evidente desvinculação da legislação do Estado territorial sugerem que, na realidade, este perdeu tanto sua soberania jurídica quanto política. Contudo, as novas formas de governança não são democraticamente estruturadas, não prestam contas a um corpo de cidadãos nem os representam. Em 
suma, o Estado nacional, democrático, constitucional e soberano, não parece mais ser a fonte legítima exclusiva das mais importantes decisões coletivas vinculativas; os legislativos eleitos já não monopolizam ou hierarquizam a elaboração das leis; os tribunais ou parlamentos nacionais já não são as instâncias supremas na hierarquia jurídica; o vínculo entre a soberania territorial e a político-jurídica dissolveu-se, e a própria soberania desagregou-se, fragmentou-se e tornou-se complexa (Cutler, 2001; Jayasuriya, 2001:445; Haufler e Porter, 1999). Por outro lado, as estruturas detentoras do poder efetivo impõem decisões, criam leis capazes de produzir efeito real, estipulam regras e são imbuídas de um ethos gerencial: não se podem dizer internamente democráticas, transparentes ou responsabilizáveis ${ }^{3}$. A substituição do conceito de governo pelo de governança capta esse estado de coisas ${ }^{4}$.

Nessas circunstâncias, não é de admirar que os teóricos da democracia depositem mais uma vez suas esperanças na sociedade civil para gerar solidariedade, tornar públicas as grandes questões e democratizar a ordem mundial emergente. Esses teóricos acreditam que uma sociedade civil em escala global poderia compensar o déficit democrático da nova ordem mundial ${ }^{5}$. Só que nem sempre está claro o que eles entendem por sociedade civil e de que maneira essas funções seriam desempenhadas no novo contexto. Alguns estudos combinam descrições empíricas de organizações, movimentos e redes transnacionais com teorias normativas sobre uma sociedade civil global emergente, que seria o lócus potencial para a democracia mundial e um equivalente funcional do Estado nacional (Held, 1995; Kaldor, 1999). Argumentam que a sociedade civil mundial avança onde os Estados não mais progridem, isto é, no suprimento de novas bases de identidade, solidariedade, coordenação, regulação e controle (Pasha e Blaney, 1998; Linklater, 1999). Outras análises interpretam a sociedade civil transnacional, composta de redes, organizações não-governamentais e movimentos sociais, mais como um veículo essencial do que como o lócus democratizador das governanças local e global. Segundo essa perspectiva, a sociedade civil é uma matriz de normas liberais e democráticas ou de princípios morais que configuram, orientam ou constrangem outros atores, instituições e ocupantes oficiais de postos do poder público (Kaldor, 1999; Falk, 2000; Thoma, 2001). Há ainda aqueles que argumentam com base nos modelos gerenciais de dispersão e diluição dos poderes do governo nas institui- 
ções da "sociedade civil" e na economia. Nessas análises, a "sociedade civil" diz respeito ao papel impositivo das agências e organizações privadas mobilizadas para fiscalizar o cumprimento das normas e executar funções de governo estruturadas em múltiplos níveis (cf. Jayasuriya, 2001:457). A suposição aqui implícita é que, se esse governo trocasse a estratégia de comando e controle estatal da regulação pela experimentação, aprendizado adaptativo e colaboração com importantes grupos não gerenciais, a "sociedade civil" promoveria a inovação e a inclusão (Sirianni e Friedland, 2001:23; Dorf e Sabel, 1998). Parece-me evidente que esta última abordagem tem pouco a ver com democratização ou crítica - na verdade, podemos interpretá-la como um disfarce para a privatização de antigos mecanismos públicos de regulação e fiscalização (Cohen, 2002b:151-180). A proposta de uma sociedade civil global talvez seja um ideal inatingível, enquanto o modelo de produção de normas internacionais parece fraco e amorfo demais para impor sanções a atores poderosos e poderia converter-se em uma ideologia justificadora de ações bastante incivis em vez de instrumento de controle, mesmo indireto ${ }^{6}$.

É aí que mora o problema. Sem um mapa que nos guie por todos esses discursos e modelos conflitantes de sociedade civil, arriscamo-nos a cultivar um otimismo ingênuo ou a assumir uma atitude francamente ideológica quanto à capacidade democratizante e à natureza e papel mundial da sociedade civil. O que está faltando é uma reflexão sistemática e cuidadosa sobre o modo pelo qual a globalização transformou os parâmetros fundamentais da sociedade civil e como essas mudanças afetam o impacto potencial da sociedade civil nas estruturas nacionais, regionais e transnacionais. Sem uma reflexão meticulosa, não temos condições de perceber o que é novo e o que é possível, e corremos o risco de sobrecarregar o conceito de sociedade civil com funções reguladoras ou democratizantes que ela provavelmente não pode realizar.

A intenção deste artigo é oferecer essa reflexão. Para começar, defino o conceito de sociedade civil elaborado no contexto do Estado nacional. Depois, apresento uma concepção dos parâmetros fundamentais da versão que elaborei junto com Andrew Arato sobre o que já se tornou "um conceito essencialmente controverso" ${ }^{7}$. Em seguida, analiso como esses parâmetros devem ser repensados no contexto da globalização. Interessa-me especialmente avaliar a possibilidade de as sociedades civis "globalizadas" ajudarem a promover direitos, democra- 
cia e justiça social no mundo contemporâneo, evitando ao mesmo tempo a armadilha da "analogia local".

Mas é preciso fazer uma advertência: não subscrevo a tese "forte" da globalização que relegou o Estado nacional à lata de lixo da história. Prefiro um entendimento "fraco" do conceito, que ainda atribui ao Estado importantes aspectos de soberania e continua a ver a sociedade política nacional como referente decisivo para os atores civis. Contudo, é fato que a soberania do Estado está parcialmente desagregada; alguns de seus elementos foram deslocados "para cima", para o âmbito de organismos regionais, internacionais ou globais, e "para baixo", ao nível de atores privados e locais. Em síntese, existem camadas adicionais de instituições políticas e jurídicas independentes do Estado, que o complementam, mas não o substituem.

\section{O CONCEITO DE SOCIEDADE CIVIL NO CONTEXTO DO ESTADO "SOBERANO"}

Entendo a sociedade civil como uma esfera de interação social diferenciada da economia e do Estado, composta de três parâmetros analiticamente distintos: pluralidade, publicidade e privacidade. A moderna sociedade civil "autônoma" nasceu de processos de constituição e mobilização independentes. Institucionalizou-se e se generalizou mediante leis e direitos subjetivos que, por sua vez, estabilizaram a diferenciação social. Por isso, é importante salientar que o aparecimento da sociedade civil aconteceu junto com o desenvolvimento do moderno Estado territorial soberano. Em outras palavras, foi a vinculação do Estado ao direito e o desenvolvimento da soberania e do constitucionalismo jurídico interno que permitiram o surgimento do modelo tripartite. O constitucionalismo e o governo representativo, isto é, o nascimento de uma sociedade política (partidos), responsiva e responsabilizável, e de uma sociedade jurídica autônoma (juristas, tribunais), tornaram-se indispensáveis para a estabilização da diferenciação entre o Estado moderno, a sociedade civil e a economia de mercado. É claro que o reconhecimento por parte da "sociedade internacional" de um Estado soberano dentro de um sistema de Estados também foi crucial: a soberania interna veio junto com a soberania externa, embora também seja verdade que o desenvolvimento da sociedade civil não dependeu da atribuição a um Estado de uma soberania externa "westfaliana" absoluta (Krasner, 1999; Sorensen, 1999). 
Os mais importantes teóricos da sociedade civil no século XIX tinham uma visão peculiar dos três parâmetros acima mencionados (Cohen e Arato, 1992, prefácio e introdução; Cohen, 1999b). O conceito de pluralidade dizia respeito à associação voluntária, que incluía as interações face a face e as organizações nacionais baseadas na iniciativa de grupos locais. Publicidade referia-se a reuniões públicas de caráter civil, realizadas em espaços "públicos", como cafés, tabernas, clubes, parques, bibliotecas, hotéis, sedes de prefeituras, destinadas à articulação de interesses comuns e sua interconexão por intermédio do veículo de comunicação de massa da época, a imprensa. Privacidade referia-se à autonomia do indivíduo, institucionalizada em direitos que abrangiam o habeas corpus e o devido processo judicial, o direito à privacidade do lar e do matrimônio, a liberdade de consciência e as liberdades de mercado ${ }^{8}$. A Lei Magna, no sentido do conjunto de direitos subjetivos constitucionais, garantia da estrutura de autonomia da coletividade e do indivíduo, bem como da diferenciação da sociedade civil em relação ao Estado e à economia, assegura a institucionalização da sociedade civil (ver Habermas, 1996b:82-131). Dessa forma, a constitucionalização do Estado implicou uma autolimitação da sociedade política em face da sociedade civil, protegendo esta última de desaparecer, sufocada pela superpolitização. Em outras palavras, os direitos constitucionalizam a diferenciação entre a sociedade civil (com suas organizações informais, pluralidade interna e públicos civis) e os sistemas administrativos e políticos do Estado, que formulam decisões coletivas e compulsórias e são organizados pelo poder do Estado - ou pelo power medium, conforme a expressão de Habermas.

Um sistema judiciário (inclusive a polícia) guiado por princípios do Estado de direito e uma cultura jurídica que obrigue seus membros a se comprometerem com normas de imparcialidade são fundamentais para o processo mediante o qual os projetos particularistas de indivíduos associados e comunicativos da sociedade civil sejam compatibilizados e inspirados pelos princípios universalistas das democracias constitucionais modernas (Cohen e Arato, 1992:1-117; Cohen, 1999b:212-214). E são também essenciais para a generalização da confiança.

Essas três dimensões da sociedade civil foram a bem dizer concebidas para estar em relação recíproca com os setores políticos institucionalizados do sistema político e jurídico (parlamentos e tribunais), por in- 
termédio das organizações da "sociedade política" (partidos) e da sociedade jurídica (advogados e juristas em geral), dedicadas à aquisição e exercício do poder e à elaboração de decisões coletivas vinculativas para toda a sociedade. Fundamentais nessa concepção geral foram a existência de uma cadeia de influências ligando a sociedade civil ao sistema político, por meio da sociedade política, e uma relação de mediação ligando as organizações representativas (partidos empenhados na formação da vontade coletiva e na agregação de interesses) e os organismos representativos (parlamentos dedicados à formação da vontade legislativa).

Já destaquei em outro trabalho que os autores europeus do século XX que estudaram a sociedade civil acrescentaram três componentes fundamentais ao seu entendimento (Cohen e Arato, 1992:1-117). O primeiro, salientado por Gramsci, foi a ênfase na dimensão cultural e simbólica da sociedade civil e seu papel na geração do consentimento (hegemonia) e, por decorrência, na integração da sociedade (Gramsci, 1971:206-277; Anderson, 1977; Cohen e Arato, 1992:142-159). A principal contribuição de Gramsci foi conceber a sociedade civil ao mesmo tempo como campo simbólico e como conjunto de instituições e práticas que são o lócus da formação de valores, normas de ação, significados e identidades coletivas. Dessa forma, a dimensão cultural da sociedade civil não é dada ou natural; ela é antes um lugar de contestação social: suas associações e redes constituem um campo de luta e uma arena onde se forjam alianças, identidades coletivas e valores éticos. Visões antagônicas da sociedade civil são mobilizadas em uma luta contínua, seja para manter a hegemonia cultural de grupos dominantes, seja para afirmar a contra-hegemonia de atores coletivos subalternos. Assim, nenhuma concepção da sociedade civil é neutra, nem a de Gramsci, e sempre faz parte de um projeto de construção de relações sociais, formas culturais e modos de pensar da sociedade.

Uma segunda contribuição importante foi a de Touraine, Melucci e outros, que enfatizaram o aspecto dinâmico, criativo e contestador da sociedade civil - a visão das associações informais e dos movimentos sociais como distintos das associações e instituições voluntárias mais formalizadas e das organizações de classe (partidos, sindicatos) (Touraine, 1981; Melucci, 1985:798-816; 1980; Cohen e Arato, 1992:492-564). O reconhecimento dessa dimensão nos permite articular e transitar entre duas perspectivas: a sociedade civil como fonte 
dinâmica e inovadora para a tematização de novos problemas; formulação de novos projetos; criação de novos valores e novas identidades coletivas; e a sociedade civil como autonomia cívica institucionalizada. Permite também considerar que, por sua capacidade dinâmica (ação coletiva), o formato institucional da sociedade civil e da sociedade política pode se tornar alvo de lutas pela democratização. Vê-se, portanto, que o acréscimo fundamental do século XX à conceituação da pluralidade societária foi a ênfase nos movimentos sociais, como importante manancial de inovação, experimentação e participação cívica, com uma função essencial para o sistema político de despertar a consciência para novos problemas e questões.

A outra importante contribuição que gostaria de ressaltar é a concepção deliberativa da esfera pública a que se referem Jürgen Habermas e seus seguidores (Habermas, 1989; Cohen e Arato, 1992; Calhoun, 1992). A categoria de esfera pública já estava presente em definições anteriores da sociedade civil, mas seu papel de mediação entre o particular e o geral só se tornou claro recentemente. Nos públicos civis, as pessoas discutem assuntos de interesse comum como seres iguais e informam-se sobre fatos, acontecimentos e sobre as opiniões, interesses e perspectivas de outros. O debate em torno de valores, normas, leis e políticas gera uma opinião pública politicamente relevante. Além disso, por intermédio dos meios de comunicação de massa - na primeira metade do século XX, tratava-se da imprensa, rádio e televisão-, a esfera pública estabelece uma mediação entre inúmeras miniaudiências que se desenvolvem entre e dentro de associações, movimentos, organizações religiosas, clubes, centros de encontro de cidadãos conscientes e de simples convívio social. Sem dúvida, existem públicos políticos e civis diferenciados e institucionalizados, fracos e fortes ${ }^{9}$. No entanto, em toda concepção liberal-democrática, a finalidade de uma opinião pública formada discursivamente é influir nos debates travados nas esferas decisórias políticas e jurídicas pertinentes (legislativos, tribunais constitucionais) e obter controle informal sobre as ações e decisões dos governantes e legisladores (princípio da receptividade). A liberdade de acesso e a participação paritária (direito igual de emitir opinião) são o ideal de regulação de todos os arranjos institucionais que reivindicam uma legitimidade democrática; todos os cidadãos sujeitos à lei deveriam ter o direito de participar e de expressar suas opiniões, de tentar exercer influência, e todos os participantes deveriam ser capazes de fazê-lo em igualdade de condi- 
ções ${ }^{10}$. Juntamente com eleições democráticas, essa idéia implicou, pelo menos no século XX, uma certa visão dos procedimentos da soberania popular: a influência exercida pelos meios de comunicação de massa e a prestação de contas realizada pela sanção eleitoral são os mecanismos que garantem que um governo representativo realmente represente (Habermas, 1996a:462-490; Cohen, no prelo).

No estudo teórico que realizei com Arato sobre o conceito de sociedade civil, procurei explicar e justificar a concepção tripartite legada pelos principais autores dos séculos XIX e XX, tomando por base a distinção dos habermasianos entre sistema e mundo-da-vida e suas implicações institucionais (Cohen e Arato, 1992, cap. 9). O argumento utilizado é o de que as instituições e os atores pertencentes aos dois subsistemas coordenados por via do poder e do dinheiro - Estado e economia capitalista de mercado - estão sujeitos a uma série de restrições que não afetam os atores da sociedade civil. Em outras palavras, nessas instituições, os atores estão diretamente envolvidos com o poder do Estado e com a produção econômica, que buscam controlar e administrar. Por esse motivo, não têm condições de subordinar critérios instrumentais e estratégicos aos padrões de integração normativa e social ou à comunicação irrestrita que caracteriza a sociedade civil. Assim, apesar de nos referirmos à "sociedade política" e à "sociedade econômica" como mediadoras entre a sociedade civil e o Estado ou a economia, respectivamente, e embora delas façam parte diferentes grupos - partidos políticos, parlamentos, sindicatos, estruturas de barganha coletiva e co-determinação-, ambas se norteiam por imperativos distintos dos que comandam as instituições da sociedade civil. Os setores decisórios no âmbito do Estado sofrem restrições formais e temporais (devem suspender as discussões em algum ponto e tomar uma decisão); na empresa privada, os decisores econômicos, por mais que discutam problemas e questões internas, como os impactos sociais e ambientais das medidas tomadas, não podem se furtar aos imperativos do lucro e da produtividade. Assim, embora a legalização dos sindicatos, da negociação coletiva e da co-determinação seja uma expressão do desenvolvimento da sociedade econômica, as limitações impostas pelo uso efetivo do poder e do dinheiro não podem ser ignoradas. Já na sociedade civil, os atores não visam à conquista do poder do Estado ou à organização da produção; em vez disso, tentam exercer influência pela participação em associações e movimentos democráticos e por meio da mídia pública. Isso 
obviamente supõe que as instituições e organizações da sociedade política e econômica são receptivas à influência da sociedade civil, que estabelecem "sensores" no interior do Estado e da economia para viabilizar tal coisa. Por "sensores" refiro-me aos espaços públicos institucionalizados dentro do Estado e das corporações, acessíveis à influência dos atores relevantes: o conjunto dos cidadãos, no primeiro caso, operários ou empregados e, mais indiretamente, os consumidores, no segundo.

Entendendo a interação comunicativa como $o$ grande mecanismo coordenador da sociedade civil, em vez do dinheiro ou do poder, e interpretando a autonomia de comunicação - a liberdade dos atores na sociedade para organizar, criticar e reafirmar normas, valores, identidades e significados por meio da interação comunicativa - como traço característico da sociedade civil, procuramos enfatizar o potencial crítico desta última no que se refere às normas e projetos, sua capacidade de exercer influência na sociedade política e a importância de proteger a sociedade civil contra a "colonização" pelo dinheiro ou pelo poder. Recente exposição de nosso conceito distingue-o da visão liberal da sociedade civil (Chambers, 2002:94), já que esta concebe a escolha individual e a associação voluntária, e não a interação comunicativa e os públicos civis autônomos, como a característica definidora da sociedade civil. É certo que nossa explicação inclui a associação voluntária, mas a propõe como um parâmetro entre outros. A teoria liberal, ao contrário, esconde o problema da colonização, com o que a instrumentalização do dinheiro e da política subjuga a natureza da sociedade civil (ibidem). Além disso, o papel democratizante dos atores civis fica obscurecido: um papel para o qual a esfera pública da sociedade civil, difícil de conceber como associação voluntária ou compreensível como "escolha" individual, é decisiva. O que importa neste caso é a interação comunicativa dos atores civis, e não a pulverização de escolhas particulares ${ }^{11}$.

Portanto, conforme declarava a primeira frase do estudo que Arato e eu escrevemos em 1992, nosso modelo de sociedade civil visava ser uma contribuição para a teoria democrática (Cohen e Arato, 1992:vii). Nesse trabalho, propusemos deslocar a problemática central da teoria da democracia para a questão dos canais de influência entre as sociedades civil e política. Nosso modelo, ademais, chamava a atenção para a configuração institucional e a articulação interna da própria sociedade civil. Defendemos a democratização da sociedade civil (da 
família, da vida associativa e da esfera pública, por exemplo), no intuito de tornar suas instituições nucleares mais justas, igualitárias e abertas. Por fim, nosso modelo apontava para uma "continuação reflexiva" do Estado de Bem-Estar Social e se opunha à sua substituição pela economia neoliberal (idem:464-487).

Reconhecemos, é verdade, a seriedade do ataque neoconservador e neoliberal ao Estado de Bem-Estar Social e a dose de verdade contida na crítica de esquerda à dependência e fragmentação social criadas por determinadas características dos sistemas assistenciais (colonização do mundo da vida). Entretanto, rejeitamos o argumento de que os procedimentos ou dispositivos estatais de resolução de conflitos (negociação coletiva, direito de co-determinação etc.) reduzissem ipso facto a autonomia da sociedade civil ou a espontaneidade de associação. Por "continuação reflexiva do Estado de Bem-Estar Social" nos referimos à necessidade e à possibilidade de descobrir alternativas aos meios ineficientes ou destrutivos de estímulo ao crescimento. Em outras palavras, os dilemas da regulação decorrentes da imposição e do controle vertical por parte do Estado devem ser levados a sério da mesma forma que o efeito fragmentador de certos tipos de intervenções. Só que, para tanto, teríamos de desagregar o termo "Estado de Bem-Estar Social" para verificar precisamente quais tipos de práticas, regulamentos e disposições administrativas e legais de "benefícios sociais" resultam em quais efeitos.

Como afirmei em 1992, provisões como a seguridade social, seguro-saúde e seguro-desemprego, programas de treinamento ocupacional e medidas de apoio familiar, como creches e licença maternidade, ou a legislação referente à negociação coletiva e outros procedimentos relativos à resolução participativa de conflitos, não debilitam a sociedade civil. Longe de criarem dependência e fragmentação, dispositivos procedurais ajudam a constituir a sociedade econômica (civilizando a economia), enquanto as medidas substantivas provêem as precondições básicas para a autonomia $e$ a solidariedade no interior da sociedade civil. Argumentei naquele trabalho que, especialmente no caso do sistema americano, outros aspectos, por exemplo, as políticas sociais que selecionam os beneficiários em função da renda [means-tested social policies], e alguns equívocos paternalistas, como a norma de habilitar uma família à assistência social desde que haja um homem adulto e fisicamente capaz no domicílio, humilham, fragmentam e criam dependências. Conforme Linda Gordon, Robert Lie- 
berman e, posteriormente, Bo Rothstein mostraram, em trabalho posterior, a principal diferença se dá entre benefícios universalistas e programas intrusivos que selecionam os beneficiários pelo nível de renda. Gordon e Lieberman demonstraram a existência de pressupostos de raça e gênero subjacentes às políticas sociais seletivas por nível de renda nos Estados Unidos, desde o New Deal. Rothstein, por sua vez, afirmou que, diferentemente das políticas universalistas, os programas sociais de tipo means-tested, que "colonizam" o mundo da vida, fragmentam os atores e destroem a confiança e o capital social da sociedade civil (Fraser e Gordon, 1994; Lieberman, 1998; Rothstein, 1998). Portanto, é uma questão complexa determinar quais regras, benefícios e proteções fornecidos pelo Estado fortalecem ou debilitam a sociedade civil e a democracia.

Em um estudo posterior, Andrew Arato e eu retomamos a idéia de um paradigma jurídico reflexivo como forma de evitar a criação de "regulatory trilemmas", quando a regulação estatal, imposta de cima para baixo, ocorre em áreas onde não é conveniente ${ }^{12}$. A idéia novamente, é que a regulação estatal é indispensável para uma sociedade civil e econômica sadia; o problema está na sua forma. Contrariando os teóricos dos sistemas, de quem tiramos o conceito, evitamos o evolucionismo argumentando em favor de uma relação reflexiva com o próprio direito reflexivo. Em outras palavras, acreditamos que formas reflexivas de regulação jurídica devem substituir o enfoque do domínio e controle da regulação previdenciária em setores essenciais, mas certamente não em todos ${ }^{13}$. O principal argumento do paradigma reflexivo é que é possível escolher entre formas jurídicas e tipos de "intervenções assistenciais" a fim de fortalecer a sociedade civil, garantir justiça social e proteção contra efeitos colaterais adversos. Haveria uma espécie de afinidade eletiva (wahlvenwandtschaft) entre a perspectiva da sociedade civil e o paradigma reflexivo do direito. No entanto, certas provisões estatais universalistas básicas, como assistência médica universal ou a idéia de uma renda mínima, não podem e não devem ser substituídas nem pela privatização nem pelo direito reflexivo.

Isso é compatível com a tese de que algumas formas de relacionamento entre o Estado e a sociedade civil são melhores do que outras, do ponto de vista da vitalidade da própria sociedade civil. Em sua análise sobre o "modelo sueco", Rothstein afirma isso. Mostra que as formas adequadas de "neocorporativismo", que promoveram a confian- 
ça vertical e a autolimitação por parte dos parceiros sociais e do Estado, não abalaram a confiança horizontal que é fundamental para a associação civil ou seu advento em várias esferas (Rothstein, 1998). O governo teve um importante papel de facilitação, mas não se sobrepôs aos atores sociais: não sufocou a sociedade econômica ${ }^{14}$. Ao que parece, uma vez abandonadas as restrições ao papel do governo e com a intervenção mais direta do sistema político, desfez-se a confiança vertical construída no modelo mais antigo. Isso repercutiu na confiança horizontal, para usar a linguagem de Putnam. Essa análise parece confirmar as descobertas do modelo do direito reflexivo e da idéia da "continuação reflexiva do Estado de Bem-Estar" como fundamentais para a manutenção da vitalidade de uma sociedade civil.

O modelo que desenvolvi com Arato adotou explicitamente o pressuposto do Estado soberano como objetivo e referente fundamental. De fato, partimos da premissa tácita de que a sociedade civil e o Estado são contíguos. Presumimos que os indivíduos aos quais se aplicam as prerrogativas de pluralidade, publicidade, privacidade, portadores de direitos subjetivos e objeto de proteções da lei (legalidade) são cidadãos do Estado em cujo território e sob cuja jurisdição vivem. E sua atividade cívica tem por finalidade influir nas decisões políticas dos seus respectivos Estados e o propósito de fazê-los responder por tais atos. Partimos do pressuposto de que os cidadãos, como autores e objetos do direito, subordinados à mesma jurisdição e às mesmas regras, participam de certa forma de um destino comum. Definimos a cidadania como fundamento para a solidariedade do Estado assistencial e da justiça social: "nós" insistimos em afirmar que "nossos" representantes elaboram leis, políticas públicas e regulamentos que propiciam a base social para uma cidadania de peso, para a justiça e a solidariedade social.

Assim, embora a "sociedade civil" não seja uma organização com critérios de pertencimento, como é o Estado-nação, e apesar de não ser necessário atribuir exclusivamente a cidadãos os parâmetros (e direitos) da sociedade civil, é verdade que nossa concepção moderna continha essa premissa. Conseqüentemente, na sociedade civil, os atores dirigem-se aos seus respectivos Estados e são objeto de suas ações, as associações organizam-se nos planos local, regional e nacional, mas não no supranacional; a participação no debate público, a dissensão e a crítica fazem parte de um processo de construção da opinião coletiva e da formação da vontade dos cidadãos (a soberania popular), ten- 
do por objetivo influir no processo legislatório e nas políticas públicas de "seu" Estado representativo soberano. Entendemos que uma sociedade civil ativa e vigilante, que ademais de votar em eleições periódicas, participa desses processos, é que torna um governo representativo, democrático e justo (Manin, 1997:6, 161-193).

A despeito de algumas importantes divergências em relação às nossas idéias, todas as outras teorias sobre a sociedade civil elaboradas no último terço do século XX continham o mesmo pressuposto - de que os atores em uma determinada sociedade civil são cidadãos do Estado soberano onde residem ${ }^{15}$. Isso ocorre tanto na abordagem liberal que mencionei acima, no enfoque neocomunitário, que enfatiza o fortalecimento da integração social e de valores corretos mediante a associação espontânea (principalmente de natureza religiosa), o voluntariado e as organizações de auto-ajuda, quanto na concepção neo-republicana da escolha racional da escola de Putnam, interessada no estudo do desenvolvimento da confiança, do capital social e da virtude cívica (entendida como o privilégio imputado aos fins públicos sobre os fins privados e a disposição ou aptidão para cooperar ${ }^{16}$. Aliás, esse pressuposto está explícito na abordagem neoparsoniana de Jeff Alexander, que traduz o conceito de sociedade civil para o esquema teórico do estrutural-funcionalismo, equiparando-o ao de "comunidade societária" - a esfera da integração social. Portanto, ele define sociedade civil como uma organização com critérios de pertencimento, ou seja, como nação - uma comunidade societária fechada e contígua ao Estado -, que se caracteriza pela confiança, solidariedade e identidade entre seus membros e pela desconfiança, falta de solidariedade e diferença entre os não-membros. O estudo de Alexander centra-se na dinâmica da inclusão e da exclusão na sociedade civil americana, concebida nesses moldes. Com isso, toda diferença entre o conceito de sociedade civil e o de nação, como uma comunidade fechada de cidadãos de um Estado soberano, é finalmente suprimida.

Submeti vários desses modelos a minucioso exame crítico e analisei as diferenças que os separam de nossa concepção de sociedade civil em outro trabalho, de modo que me parece dispensável repetir aqui os argumentos ali usados (Cohen e Arato, 1992; Cohen, 1999b). Gostaria apenas de ressaltar que também discordo profundamente do enfoque neoparsoniano, que parte de um erro categorial: o conceito de sociedade civil não equivale ao de nação ou de comunidade societária, porque não é uma organização determinada por critérios de pertenci- 
mento, não constitui uma comunidade total ${ }^{17}$. Ao contrário, os parâmetros e o conceito em si de sociedade civil não são fechados: nenhum dos direitos, atividades, públicos ou formas associativas nele incluídos são privativos aos seus cidadãos ou pressupõem o Estado soberano como referente político exclusivo ou alvo único da ação cívica. É verdade que mesmo no modelo que elaborei com Arato havia a premissa tácita de que os membros de associações da sociedade civil constituem a cidadania de um Estado em particular, que é seu ponto de referência, e cujas leis e direitos são reciprocamente constituídos pelas relações comunicativas e interdependências complexas que os unem. Mas este pressuposto não é inerente ao modelo; simplesmente expressa a forma histórica de sociedade civil que estávamos estudando naquela época.

\section{O IMPACTO DA GLOBALIZAÇÃO NOS PARÂMETROS DA SOCIEDADE CIVIL}

O nível de abstração de nossa análise dos parâmetros da sociedade civil é bastante amplo para admitir outro conteúdo e outras institucionalizações de cada dimensão, que podem ser aplicadas tanto à esfera supranacional quanto à subnacional. Passo agora a examinar o impacto da globalização sobre os parâmetros específicos de nosso modelo original, na intenção de evitar as ciladas da "analogia local", que simplesmente transpõe uma análise inalterada dos parâmetros de uma sociedade civil nacional para o plano global, o que constitui, na minha opinião, um grave erro. O que desejo mostrar, ao contrário, é que a transformação dos parâmetros da sociedade civil no contexto contemporâneo da globalização impõe uma percepção descentrada da sociedade civil "globalizada". Pretendo ainda avaliar os pontos fortes e os pontos fracos dos atores da sociedade civil em face dos diferentes subsistemas da sociedade mundial no plano global, isto é, do ponto de vista de seu papel na promoção de direitos, justiça social e democracia. Analisarei em seqüência cada um desses parâmetros.

\section{Pluralidade}

No livro que Arato e eu escrevemos em 1992, interpretamos os "novos movimentos sociais" nascidos no final dos anos 50 e início dos 60 , que incluíam desde a luta pelos direitos civis até os movimentos feministas, ambientalistas, pacifistas, os grupos de defesa dos consumidores e de organização de comunidades, como um novo tipo de pluralidade 
e engajamento cívico paradigmático do século XX. Todos giravam em torno da participação em inumeráveis pequenos grupos, de âmbito local e interação face a face (como os grupos de conscientização e de auto-ajuda), do desenvolvimento de públicos de oposição (jornais, revistas, estações de rádio etc.) $e$ de mobilizações de massa mais visíveis que tinham como objetivo alcançar Washington e outras grandes cidades. Argumentamos, então, que essas novas formas de pluralidade eram indicativas da vitalidade da sociedade civil, já que envolviam formas de engajamento cívico capazes de gerar capital social e muito importantes para os projetos de democratização. Creio que essa análise pode ser aplicada a outros países da Europa Ocidental no mesmo período. Os "novos movimentos sociais" organizavam-se local e nacionalmente, mas não no plano internacional, em que pese a ocorrência de sucessivas ondas de protesto por todo o Ocidente nas décadas de 60 e 70, embora "o novo movimento social" tenha surgido em todo o planeta.

O século XXI está assistindo a uma outra mudança na forma da pluralidade. Quer se pense nos militantes que acorreram às cidades de Seattle e Gênova, quer se tenha em mente os protestos realizados em diversas cidades do mundo inteiro, no dia 15 de fevereiro de 2003, contra a guerra no Iraque, é evidente que a presença de atores vindos de muitas partes do planeta, nos dois primeiros casos, e a natureza coordenada das ações coletivas nas três situações, impõem um novo entendimento da pluralidade e do potencial de organização. A grande inovação é a "rede transnacional", que vem se convertendo na forma paradigmática de pluralidade da sociedade civil (como modo de associação e solidariedade) nesta primeira parte do século XXI. Não estou dizendo que as antigas formas de pluralidade e de organização de movimentos sociais tenham desaparecido, mas que uma nova forma e uma outra camada de "atividade associativa" vem se somando às anteriores.

Muito já se escreveu sobre o conceito de rede, de modo que vou utilizar aqui apenas uma definição operacional. De acordo com o estudo de Keck e Sikkink (1998) sobre os militantes que atuam além das fronteiras de um país, uma "ligação entre redes de computadores" consiste de estruturas comunicativas das quais participam atores situados em diferentes posições com a finalidade de influir nas políticas públicas, nos discursos, nas normas e nos processos decisórios de entidades muito poderosas. As "redes" geralmente caracterizam-se por es- 
quemas de comunicação e intercâmbio voluntários, recíprocos e horizontais. Sob outro ângulo, é possível caracterizá-las como estruturas cuja capacidade de agir é maior que a soma de suas partes ${ }^{18}$. E, de resto, envolvem a interação direta em grupos locais. Só que suas estruturas de comunicação lançam mão de modo cada vez mais freqüente dos novos meios eletrônicos, permitem o entrelaçamento de atores "locais" e "não-locais", que se conectam e discutem no ciberespaço por meio de troca de mensagens instantaneamente recebidas e respondidas. A internet facilita a expansão das interações comunicativas em escala planetária.

A meu ver, a rede é uma nova forma de pluralidade que torna possível uma nova forma de conexão social, novas formas de ação coletiva e uma "solidariedade entre estranhos" mais ampla que as anteriores. Não me refiro à "ação coletiva" ou à conexão realizada unicamente pela internet, como uma campanha por correio eletrônico ou as conversas em salas de bate-papo ${ }^{19}$. Estou pensando na articulação de grupos locais que se inter-relacionam por intermédio da rede virtual de computadores e se comunicam em parte através da nova mídia eletrônica. É essa combinação que constrói um todo maior que a soma de suas partes.

Decerto, essa interpretação está sujeita a controvérsias. Alguns afirmam que redes sempre houve e, portanto, não há novidade alguma nisso. Outros insistem em dizer que estamos diante de algo completamente novo. A diferença de opiniões baseia-se na abordagem analítica que cada um utiliza. Do ponto de vista da análise de redes sociais, essa ligação é uma das formas mais antigas de organização social. A análise tecnológica, centrada no uso dos novos meios eletrônicos, considera a rede como um fenômeno radicalmente novo, enquanto a teoria organizacional das redes se coloca em uma posição intermediária: reconhece a existência de redes no passado, mas a teoria permite explicar o novo sem cair em um falso evolucionismo ${ }^{20}$. Prefiro a última abordagem que representa, na verdade, um refinamento da definição geral de Keck e Sikkink.

A teoria das organizações diferencia a organização no formato de rede da forma hierárquica e das trocas de mercado. Foram identificados três diferentes tipos de configuração de rede: a rede de cadeia, a rede de $h u b$ (que usa um ponto de conexão, ou nodo, central) e rede com todos os canais abertos (all-channel). As diferenças dependem de 
como e se os participantes atuam com autonomia, de onde a liderança se encontra ou se distribui, de quem pode se comunicar com quem, e se e como se dá uma combinação de dinâmica hierárquica com uma dinâmica de rede. É possível haver ainda formas híbridas dessas três configurações básicas, bem como híbridos de rede e hierarquia (Arquilla e Ronfeldt, 2001:325 e passim).

Mas a organização é apenas um dos cinco níveis a considerar na análise do formato de rede. A força de uma rede também é influenciada pelos níveis narrativo, doutrinal, tecnológico e social. A rede será forte se incluir uma história que persuade e integra seus membros; se abranger estratégias e métodos colaborativos baseados em uma doutrina bem definida; se utilizar sistemas avançados de comunicação e apoiar-se em vínculos sociais e pessoais fortes. Com a devida vênia a Robert Putnam, até a forma de rede global não prescinde de uma dimensão associativa de âmbito local; do contrário, tenderá a ser muito frágil e efêmera.

É preciso deixar claro, porém, que a narrativa não é somente uma ênfase ou uma interpretação, mas uma história que expressa de modo convincente as experiências, interesses e valores das pessoas, que traz à tona e alimenta um senso de identidade, uma causa, um objetivo, uma missão (idem:328). Antigos e novos veículos de comunicação são utilizados para transmitir essas narrativas. No nível doutrinal ou estratégico, a ausência de líderes e o recurso a múltiplas estratégias são as principais inovações, como se pôde verificar nas manifestações em Seattle contra a Organização Mundial do Comércio, em 1999 (cf. idem, cap. 7). As redes podem funcionar sem acesso à internet ou a outras mídias avançadas, mas o que chama a atenção é o uso das novas tecnologias principalmente por parte dos ativistas da sociedade civil em fins do século passado e início deste. Isso age como rápido catalisador de protestos espontâneos e, ademais, ajuda a divulgar a imagem desejada da identidade ou dos objetivos da rede. Em que pese a importância de comunicações impessoais, relações pessoais de confiança se desenvolvem-se relações pessoais de confiança em "comunidades de ação" ou grupos locais de pessoas que se conhecem.

Os ativistas da sociedade civil transnacional contemporânea fazem intenso uso do ciberespaço e universalizam solidariedades locais, mas em função de questões ou áreas bem delimitadas, que envolvem interesses e valores específicos - as redes de defesa dos direitos hu- 
manos, por exemplo, evocam solidariedades diversas das que mobilizam os grupos feministas ou os defensores do meio ambiente ou, de resto, as redes comerciais. Isso faz brotar uma grande variedade de redes globalizadas que se dirigem a diferentes "subsistemas", e não a uma única sociedade civil global. Além disso, não é demais ressaltar que a forma de rede também tem sido adotada pelos atores não-estatais de conduta mais incivil - por exemplo, as redes transnacionais de terrorismo e as redes internacionais de organizações criminosas. Em outras palavras, a rede é uma forma neutra que pode ser usada para os propósitos mais diversos.

Cabe ressaltar que a forma de rede transcende as fronteiras nacionais, constrói associações transnacionais da sociedade civil e inclusive extrapola, em termos de participação, a linha divisória entre atores civis e atores estatais. Keck e Sikkink salientam que entre os principais atores podem estar movimentos sociais locais, fundações, organizações não-governamentais internacionais e locais de pesquisa e defesa de interesses (as ONGs), organizações intergovernamentais regionais e internacionais e mesmo setores do Executivo e do Legislativo, bem como igrejas, órgãos de defesa de consumidores, intelectuais e sindicatos (Keck e Sikkink, 1998:9). Houve certamente no passado movimentos transnacionais que se utilizavam de redes: as células comunistas ligadas ao movimento comunista internacional são o exemplo mais evidente. Mas, a meu ver, a principal diferença entre as antigas e as novas redes está na flexibilidade e no caráter horizontal dos vínculos que caracterizam as últimas em comparação com a estrutura organizacional hierárquica e a relativa rigidez dos laços internacionais que especificam as primeiras. Outro aspecto particularmente relevante no século XXI, ao qual já me referi, é a crescente importância da mídia eletrônica. Recorde-se que as redes não são organizações baseadas em critérios de pertencimento e, embora possam ser formadas por organizações, a palavra rede não caracteriza sua estrutura como um todo ou as ligações entre os nodos.

Não quero negar as continuidades existentes entre o formato de rede e a estrutura dos "novos movimentos sociais" da década de 60, ou mesmo de movimentos transnacionais mais antigos, como o do pacifismo. Só desejo assinalar que as novas tecnologias de comunicação tornam possíveis novas formas de articulação social e de contestação política. A internet facilita o desenvolvimento de todo um repertório de novas formas de ação, inclusive "marchas virtuais", petições 
on-line e outras, que permitem a criação de laços entre "grupos" locais com identidade de pensamento, bem como a mobilização extremamente rápida e simultânea de pessoas em muitos locais diferentes.

A influência dessas novas formas de ação coletiva se faz sentir na criação de causas e na definição de questões, no subsídio ao discurso adotado por Estados e organizações internacionais, nos procedimentos institucionais e na modificação das políticas públicas. As entidades visadas podem ser Estados, organizações internacionais, organismos políticos ou associações privadas de nível local, regional e transnacional. As redes globalizadas participam da política nacional e internacional e simultaneamente deslocam seu foco e lócus conforme o assunto em causa. Seja qual for o alvo visado - um Estado, a Organização Mundial do Comércio - OMC, as Nações Unidas ou uma corporação multinacional -, o referente da ação coletiva agora é algo que se denomina de "opinião pública mundial". Qual seu significado e como funciona esse novo elemento da sociedade?

\section{Publicidade}

É evidente que as novas tecnologias de comunicação anunciam a chegada de novas formas de publicidade. As principais inovações tecnológicas recentes são a mídia eletrônica (a internet, o correio eletrônico, o bate-papo virtual), a televisão a cabo ou por satélite e a criação dos noticiários "globais", transmitidos ao vivo durante $24 \mathrm{~h}$, entre outras.

É no espaço das novas tecnologias de comunicação que veio à tona, ou está sendo construído, um novo personagem: a "opinião pública mundial" 21 . Ao descrever os protestos de 15 de fevereiro de 2003 contra a guerra no Iraque, um repórter do The New York Times afirmou que há duas superpotências no século XXI: os Estados Unidos e a Opinião Pública Mundial. Escrita como pilhéria, a frase contém um grão de verdade; de fato, a mais importante transformação da esfera pública ocorrida neste século é a substituição do nacional pelo internacional e agora pela opinião pública "mundial", viabilizada pelos novos meios de comunicação já mencionados e evocada nos discursos tanto dos ativistas quanto das elites políticas.

Do mesmo modo que as novas formas de pluralidade, a "opinião pública mundial" é um outro plano e um outro referente que não substi- 
tui a opinião pública nacional ou os incontáveis pequenos grupos civis e contra-públicos que afloram nos níveis locais.

É possível tratar teoricamente a porosidade recíproca entre públicos parciais e gerais de duas outras maneiras. Recorrendo-se às observações da teoria das redes, os públicos serão vistos não só como fincados em associações ou meios sociais específicos, mas também como setores intersticiais: isto é, como grupos de interações comunicativas que facilitam as transições entre domínios específicos por desvincularem os atores do padrão de relações e dos modos de pensar enquistados em qualquer público dado (Emirbayer e Goodwin, 1994; White, 1995b). Vistos dessa maneira, os públicos cumprem funções essenciais de estreitamento de distâncias entre diferentes domínios de rede, favorecendo a formação de "solidariedades cruzadas".

Pode-se também recorrer ao conceito de uma esfera pública civil mais geral e abstrata de leitores, ouvintes, espectadores e, agora, de cibercomunicadores espalhados por toda a sociedade mundial para pensar sobre o que articula os participantes de públicos parciais e constitui fóruns mais gerais, isto é, os novos meios de comunicação de massa. Esses novos veículos permitem pôr em contato impessoal, ou virtual, interlocutores socialmente distantes com o objetivo de articular alianças e estabelecer orientações coletivas de ação na busca de exercer influência política. Do mesmo modo, os novos meios de comunicação de massa permitem que membros de públicos parciais se vejam como partícipes de um público maior e contribuintes para uma "opinião pública mundial".

Para tanto, a velocidade das novas comunicações é um aspecto crucial. Mas a rede e as novas mídias também facilitam a formação de um novo padrão de influência da sociedade civil. Refiro-me à capacidade de pessoas que não são necessariamente cidadãos do Estado ou membros das organizações alvo de participarem de uma política de influência ou de interesse [leverage politics]. "Militantes além fronteiras" mobilizam a "opinião pública mundial" por meio do que se denominou, com bastante propriedade, de "padrão bumerangue" (Keck e Sikkink, 1998:12-14). Trata-se do processo pelo qual associações da sociedade civil ou organizações não-governamentais de origem nacional passam por cima dos seus Estados e se vinculam diretamente a aliados transnacionais para tentar exercer pressão sobre seus Estados (ou outros Estados que tenham como alvo) a partir de fora ou 
"do alto". Uma forma de triangulação, o "padrão bumerangue" pode também incluir as demandas de populações locais desejosas de participar em projetos de desenvolvimento que afetam suas vidas e dependem de recursos ou pressões externos. Ligações estabelecidas através de redes transnacionais proporcionam aos atores locais acesso, influência e informações utilizáveis para pressionar, desde fora, os órgãos governamentais e não-governamentais relevantes. O "efeito bumerangue" implica, portanto, passar por cima de um Estado local, acionar uma rede transnacional para dar publicidade a uma questão, criar uma "opinião pública mundial" e apelar para normas e princípios acordados no plano supranacional a fim de pressionar outros Estados, organismos regionais ou organizações que, por sua vez, tentarão fazer pressão sobre o Estado cujas políticas estão em causa ${ }^{22}$.

Assim se formam públicos transnacionais, problemas ascendem à ordem do dia, a "opinião pública mundial" é construída e invocada, novas normas são fixadas, e se faz pressão e exerce influência de fora sobre o poder estatal (ou não-estatal) pertinente. Esse modelo é aplicável tanto a redes transnacionais de defesa dos direitos humanos, quanto às redes dos movimentos feminista e de preservação do meio ambiente ou à opinião pública mundial criada pelos militantes pacifistas contrários à intervenção dos Estados Unidos no Iraque. Os militantes residentes nos Estados Unidos lograram articular-se a grupos de igual pensamento, espalhados pelo mundo inteiro, os quais procuraram exercer pressão sobre a "sociedade política" que se tornou relevante no assunto: o Conselho de Segurança das Nações Unidas. Embora não se tenha evitado que os Estados Unidos realizassem seus objetivos, o governo de George W. Bush certamente perdeu legitimidade, porque, ao contrário do que ocorreu na administração de seu pai, o presidente americano jamais conseguiu alegar que contava com o apoio da opinião pública mundial. As conseqüências dessa falta de legitimação ainda se fazem sentir atualmente.

Há quatro aspectos envolvidos na publicidade: uma política de informação, cuja condição necessária é a capacidade de gerar de modo rápido e confiável informações políticas mobilizáveis nas situações em que tenham máxima eficácia; uma política simbólica, ou o recurso a símbolos e narrativas que explicam a lógica de uma situação para públicos locais e distantes; uma política de influência ou de interesses, ou a capacidade de apelar a atores poderosos para influir em uma situação em que membros mais fracos de uma rede têm pouca influência; e 
uma política de responsabilização, isto é, o esforço para fazer com que atores poderosos respeitem os princípios acordados previamente no plano nacional ou no plano da opinião pública mundial ${ }^{23}$. É realmente impressionante o grau de reflexão e auto-reflexão em torno da articulação de novas normas, a mobilização de públicos e a construção e invocação de uma "opinião pública mundial" que os membros mais atuantes da sociedade civil transnacional põem em ação.

Mas é preciso examinar também o "lado negativo" de tudo isso. Afinal, há uma possibilidade óbvia de que Estados e organizações econômicas poderosas façam uso instrumental da "opinião pública mundial" a fim de justificar práticas injustas ou ilegítimas. Exemplos notórios são os esforços recentes realizados por governos muito poderosos de invocar normas "humanitárias" ou princípios democráticos para encobrir projetos de intervenção e dominação. Visto que ainda não existem pesquisas mundiais de opinião, é impossível comprovar alegações sobre uma "opinião pública mundial". No entanto, essas alegações não passam sem controvérsia. Os novos meios de comunicação tornam-se veículos de disputa pela influência na "opinião pública mundial".

\section{Privacidade}

Já afirmei que o parâmetro da "privacidade" refere-se à autonomia pessoal conferida ao indivíduo e institucionalizada por um conjunto de direitos que abrangem desde o habeas corpus e o devido processo judicial à preservação da intimidade do lar e das associações íntimas, à liberdade de consciência e às liberdades de mercado (o direito de adquirir propriedade e a liberdade de contratação). Esse parâmetro sofreu muitas modificações, inclusive no que diz respeito à definição da privacidade como garantia da autonomia pessoal e a quem ela é concedida. Focalizarei minha análise em duas áreas principais: a da privacidade e autonomia concernentes a "associações íntimas" e a atribuição de personalidade jurídica e os direitos correspondentes a todos os indivíduos, sejam eles cidadãos ou não do Estado em que residem.

Na minha opinião, algumas das mais importantes transformações se deram no "domínio da intimidade", a esfera por excelência do privado. A perda de importância do casamento para o início e continuidade de associações íntimas, as transformações dos papéis familiares 
devido ao divórcio e novas uniões", a mudança de visão da sociedade sobre o sexo reprodutivo, de imperativo moral a escolha ética, e a entrada em massa das mulheres (casadas, solteiras, com ou sem filhos pequenos) no mercado de trabalho e na vida pública estão entre as mudanças mais relevantes. Nesse campo, como em outros, houve um processo geral de individualização que conceituou o indivíduo, e não a família, como o referente da privacidade e o portador dos direitos correspondentes (Cohen, 2002a). Sinal desta tendência é uma importante modificação no status da mulher, cujos direitos à plena personalidade jurídica e igualdade cívica foram reconhecidos, princípio este que vem se universalizando, não obstante as resistências do poder patriarcal ${ }^{24}$. A multiplicação das formas legítimas de associação íntima é um dos efeitos desse processo.

A privacidade da unidade familiar, que conferia autonomia e controle ao homem, na qualidade de chefe do domicílio, e protegia a família, entendida como uma "comunidade afetiva" contra interferências externas, foi substituída por direitos de privacidade que garantem personalidade jurídica e autonomia de decisão ao indivíduo, homem e mulher, não só para formar associações íntimas, mas também para agir dentro da família e em função de interesses privados. Uma vez atribuída plena personalidade jurídica às mulheres, que, casadas ou não, passaram a ser merecedoras de igual respeito e consideração, não é mais possível ignorar as questões de justiça geradas na esfera doméstica pela imputação de privacidade à família como unidade. Tornou-se igualmente inaceitável a interferência do Estado proibindo relações íntimas não-maritais a pretexto de serem, por definição, imorais. Os alicerces da premissa de que só há uma maneira moralmente correta de estabelecer relações íntimas foram atacados junto com a raison d'être de grande parte da legislação estatal sobre princípios morais. Em outras palavras, o caráter "natural" da velha distinção entre público e privado foi abalado juntamente com as premissas de gênero que modelavam as formas de regulação jurídica anteriores, inclusive a criação de categorias especiais às quais se atribuía o direito de privacidade.

A luta das mulheres pela igualdade de gênero foi certamente um fator importante nessas transformações. O significado da liberdade de es-

* A autora usa a expressão "recombinant family" para indicar essas transformações. [N. do T.] 
tabelecer associação íntima e do direito à privacidade realmente sofreu uma mudança radical, desde o direito de casar ou de divorciar-se à igual condição de todos os adultos para estabelecer e orientar suas relações íntimas como melhor lhes aprouver, envolvendo ou não o casamento, desde que conduzidas de modo a não violar as liberdades equivalentes ou as necessidades fundamentais de outros (filhos).

Já escrevi vários estudos sobre esse tema (Keck e Sikkink, 1998). Nesses textos, questionei principalmente os argumentos dos que consideram a multiplicação de formas de intimidade e a individualização do referente dos direitos à privacidade nesta área como sinônimo de desintegração dos valores da família e como a causa do suposto crescimento de um individualismo desmedido, atomizado, egoístico e irresponsável (idem; Cohen, 1999:235-238). O que se desintegrou não foi "a família", mas o consenso sobre o que é uma família adequada, sobre a forma que deve ter uma relação íntima apropriada e a definição do status da mulher e do homem, bem como a identidade de gênero. Além disso, direitos individualizados à privacidade, no que respeita às associações íntimas, não afetam a comunidade ou responsabilidade mútua. Pelo contrário, eles protegem os indivíduos, se e quando a solidariedade da comunidade afetiva entra em crise e os resguarda contra o uso iníquo do poder pela parte mais forte.

Não resta dúvida de que a família de hoje vem sofrendo enormes pressões. Se ocorrem processos de individualização sem o devido suporte social e institucional, os parceiros de uma associação íntima tendem a ficar sobrecarregados. A privatização das tarefas de atendimento familiar - do trabalho de educar, cuidar das crianças, oferecer atividades extra-escolares, assistir aos idosos e aos doentes - acaba criando responsabilidades injustas e insuportáveis para quem realiza esses encargos (e que ainda hoje são, em grande maioria, as mulheres), além de submeter os parceiros a enorme tensão. As inseguranças e dificuldades que afligem as associações íntimas são explicadas pela mudança institucional, individualização e insegurança econômica, de um lado, e pelo aumento da igualdade entre os gêneros, a expansão da mobilidade e das oportunidades sociais, de outro. Na ausência de um apoio social adequado, os laços familiares, agora mais frouxos e mais frágeis, correm o risco de romperem-se. O suprimento desses apoios implica ajuda financeira e remuneração para o trabalho doméstico, bem como a igualdade de oportunidades para as mulheres. Somente se forem criadas, no âmbito local, formas de solidariedade e 
comunidade, com a alocação de recursos federais para suprir essas funções (como a criação de creches nos bairros e nos locais de trabalho, de serviços de assistência a idosos e assistência médica domiciliar, de centros comunitários, a redução da jornada de trabalho para todos etc.), será possível atenuar os aspectos negativos da privatização e da individualização.

Um outra tendência que pretendo discutir a respeito do parâmetro da privacidade é a desvinculação da personalidade jurídica de uma cidadania nacional e a atribuição de direitos e proteções legais a residentes não-cidadãos - um processo que acompanhou a transformação do Estado soberano. A concessão de uma personalidade jurídica, isto é, da proteção da lei, inclusive o direito de mover processo judicial, a residentes não-cidadãos é o fato mais importante no que diz respeito a esse parâmetro. Sua relevância é comparável à transformação no domínio da intimidade, pois reconhece a igualdade, dignidade, valor moral e integridade de todos os indivíduos independentemente não só do gênero a que pertencem, mas também do seu status de cidadania. O enorme desenvolvimento do direito internacional e o tratamento de conceitos fundamentais dos direitos humanos como "jus cogens" [direito cogente] são aspectos dessa transformação. Já vimos que os Estados vêm sendo submetidos à crescente pressão de acordos internacionais e instituições transnacionais no sentido de proteger os direitos humanos de seus cidadãos e residentes estrangeiros (mesmo que ilegais). Esse novo regime jurídico globalizado e "cosmopolita" é um sinal de que os governos e os tribunais nacionais já não constituem a autoridade suprema ou a fonte única no que concerne aos direitos básicos do indivíduo.

Tais mudanças me levam às seguintes conclusões teóricas: o status de personalidade jurídica deveria ser desvinculado do status de cidadania como princípio de pertencimento a um determinado Estado e, portanto, deveria estar sob a proteção de múltiplos níveis de jurisdição e sanção legal. Na realidade, perante os tribunais internacionais (da Câmara Internacional do Comércio à Corte Européia de Justiça) e os organismos governamentais de federações regionais (como os Estados Unidos), o conceito de "cidadania" passou a significar "personalidade jurídica" e status legal, não o pertencimento a um corpo de cidadãos (demos) delimitado por uma identidade nacional. Uma conseqüência dessa situação é a faculdade de usufruir de uma ampla gama de direitos em Estados dos quais as pessoas não são cidadãs ${ }^{25}$. 
Outra é o direito dos indivíduos que são cidadãos de apelar a tribunais supranacionais para proteger seus direitos contra a ação de seus próprios Estados. O "efeito direto" dos tribunais regionais sobre os indivíduos nos Estados-membros da União Européia e a criação de cortes mundiais tornam isso possível. Essas proteções legais aplicam a capa protetora da personalidade jurídica e, em conseqüência, autonomia e privacidade pessoal, cruciais para uma sociedade civil, a todas as pessoas, embora a definição do conteúdo dos direitos em questão seja politicamente controversa e diferente em contextos diversos.

No entanto, seria uma irresponsabilidade não mencionar as graves ameaças à privacidade e autonomia pessoal possibilitadas pela globalização e pelos novos meios eletrônicos de comunicação (técnicas de vigilância, monitoramento da rede etc.). As liberdades civis vêm sendo seriamente ameaçadas após os acontecimentos de 11 de setembro, e os Estados começaram de repente a fazer valer neste domínio uma forma perigosa e não controlada de soberania, em nome da "segurança nacional". Estados poderosos têm suspendido os direitos à privacidade e à defesa na Justiça, o habeas corpus e o direito de instaurar processo, sobretudo, mas não somente aos não-cidadãos. Em suma, é possível que se esteja assistindo ao início de tendência contrária aos importantes processos jurídicos globalizados de preservação da privacidade, pluralidade e publicidade. Mas a tendência positiva ainda está viva e constitui um fundamento para a contestação judicial e a resistência por parte de juristas e demais atores da sociedade civil.

\section{LEGALIDADE E GLOBALIZAÇÃO}

Embora o direito não seja um parâmetro da sociedade civil é o veículo por meio do qual ela se institucionaliza. No entanto, a dimensão da legalidade também sofreu importantes modificações entre fins do século XX e início do XXI, com grandes repercussões para a sociedade civil. Também nesse aspecto as mudanças se expressaram em uma nova terminologia: são exemplos disso a substituição da palavra governo por "governança", para designar a ordem transnacional, e os novos discursos jurídicos da "soft law" e do "constitucionalismo societário" ${ }^{26}$. O que está em jogo é, de uma parte, um deslocamento das funções regulatórias da órbita de instituições públicas para a das instituições semiprivadas e, de outra parte, o deslocamento da regulação do plano do Estado nacional para o de instituições públicas transnacionais. A questão-chave é saber se a nova "verrechthlichung" (legalida- 
de) garante a expressão autônoma e a solidariedade dos atores da sociedade civil.

O termo "governança" diz respeito a sistemas de poder que contam com mecanismos de controle regularmente exercidos e que geram aquiescência sistemática sem exigir a presença de uma autoridade política ou jurídica formal - um "governo" - e sem incluir necessariamente uma hierarquia ${ }^{27}$. Objetivos são definidos, diretrizes determinadas, políticas aplicadas e normas estabelecidas com uma dependência mínima de uma estrutura hierárquica de comando ou da referência a um "legislador soberano". As associações e instituições não-governamentais vêm se tornando fontes cada vez mais importantes do direito. Assim, "governança" remete a várias dimensões do sistema global emergente e a importantes fatos de ordem local. As novas formas de governança causam uma proliferação de organizações voltadas para as necessidades, problemas e oportunidades com que as pessoas se defrontam no dia-a-dia e que resultam das novas interdependências criadas e possibilitadas pelo capitalismo global.

Dizem alguns que a globalização da governança e o surgimento da soft law $w^{* *}$ obriga a repensar a doutrina tradicional das fontes do direito, segundo as quais a distinção entre o que é direito e o que não é baseia-se numa hierarquia de normas jurídicas. A Constituição de um Estado nacional, por esse modelo, é a lei máxima que remete à legislação política democrática (a vontade do soberano) como fonte suprema da validade legal. Outros fenômenos normativos, baseados em regras, devem ser entendidos ou como legislação delegada, que depende do reconhecimento por parte de uma ordem jurídica oficial, ou não constituem lei. A governança globalizada parece romper com esse modelo de hierarquia de normas. O novo dilema é a elaboração de normas em foros públicos ou privados que fogem ao controle dos Estados soberanos no contexto de uma sociedade global "heterárquica" cada vez mais fragmentada (Black,1997). Alega-se que o pluralismo legal substitui a soberania e a hierarquia jurídica na sociedade mundial globalizada.

\footnotetext{
** Soft law (literalmente direito "brando") refere-se a atos ou acordos juridicamente não vinculativos, em oposição à hard law (literalmente direito "férreo") que determina regras juridicamente compulsórias. [N. do T.]
} 
Disso decorre o novo discurso do "constitucionalismo societário" 28 . O suposto básico é que devemos separar a idéia de Constituição dos laços históricos que a ligam ao Estado e generalizá-la para entidades não-estatais e supra-estatais, se quisermos nos manter atualizados com relação aos fatos do mundo contemporâneo. A tese é que o desenvolvimento da sociedade mundial, funcionalmente diferenciada em uma pluralidade de sistemas globalizados e globalizantes, gira em torno da criação de constituições, que tanto constituem quanto constitucionalizam cada domínio. Em suma, não haveria apenas a governança e o direito "brando", não vinculativo, mas também o direito constitucional em cada subsistema em processo de globalização.

Mas o que é uma Constituição nesse discurso? Que critérios nos permitem dizer que um determinado domínio está constitucionalizado? A resposta para essa forma de pensamento é que uma Constituição é uma questão de "vinculação estrutural" entre subsistemas específicos e normas legais.

Para nós que estamos habituados ao conceito de constitucionalismo aplicado a Estados nacionais, a proposição parece muito obscura. Os teóricos dos sistemas insistem em dizer que, mesmo no âmbito estatal, a função essencial das constituições é garantir a pluralidade da diferenciação social. Desse ponto de vista, o importante na constitucionalização é liberar o dinamismo de cada subsistema e, ao mesmo tempo, institucionalizar mecanismos de autocontrole que evitem sua expansão para toda a sociedade, sufocando-a em um pântano de regulamentos.

Segundo se alega, existe "vinculação estrutural" entre o direito e cada subsistema globalizado: política, economia etc. Mas isto será de fato constitucionalismo ou mero acúmulo de regulamentos e montanhas de legislações? Fazer essa distinção é importante para a teoria da sociedade civil porque a primeira hipótese, e não a segunda, é que é fundamental para sua proteção e institucionalização. Cabe lembrar a propósito o argumento de Hart de que, para haver uma ordem jurídica, é preciso diferenciar entre regras primárias e regras secundárias, entre normas de conduta e normas para a produção de leis. Uma constituição é um componente de uma ordem jurídica formada em parte por regras secundárias ou regras para a mudança, inclusive as que regulam a modificação das próprias regras secundárias. De igual importância é a existência de uma regra de reconhecimento que indique 
aos componentes do sistema judiciário, sobretudo os tribunais, como discernir uma lei válida - isto é, uma regra invocável para dirimir conflitos sobre isto e sobre jurisdições, mostrando-lhes, o que são regras primárias e secundárias e quem tem autoridade para fazê-las. Em outras palavras, a reflexividade é essencial para uma ordem legal e mais ainda para uma constituição que, ainda por cima, confere poderes além de impor obrigações. As fontes do direito podem ser muitas, mas deve haver algo para unificá-las e hierarquizá-las para que possa existir uma ordem jurídica e uma constituição. Em resumo, só há ordem jurídica e, evidentemente, ordem constitucional se existirem regras secundárias que especifiquem o modo de determinar conclusivamente regras primárias, como introduzi-las, eliminá-las, modificá-las e definir de maneira irrevogável em que consiste sua violação ${ }^{29}$.

Ora, não há uma constituição global total para a sociedade mundial que se aproxime minimamente desses critérios e tampouco existe uma única sociedade civil global. Do ponto de vista da teoria dos sistemas, não faz o menor sentido defender esse tipo de coisas, porque a idéia nuclear é que a sociedade mundial é radicalmente destituída de centro: nenhum subsistema dentre os vários subsistemas funcionalmente diferenciados pode representar a totalidade. A teoria contemporânea dos sistemas rejeita fortemente a idéia da pars pro toto [tomar a parte pelo todo] seja para o Estado em uma sociedade nacional, seja para a política internacional. Globalização e constitucionalização em uma sociedade mundial são processos policêntricos.

Assim, o discurso do "constitucionalismo societário" inclui uma proposição um pouco diferente, isto é, a de que existe uma constituição global para cada subsistema globalizado da sociedade internacional, incluindo o subsistema político. Os constitucionalistas chamam a atenção para a organização heterárquica dos tribunais de justiça no centro do novo regime jurídico global, assim como para a centralização dos remédios jurídicos em foros supranacionais, como a Corte Européia de Justiça, o Tribunal Penal para a ex-Iugoslávia, o Tribunal Penal para o Ruanda, a Câmara Internacional do Comércio, as comissões de verdade instaladas pelas Nações Unidas, ao lado dos tribunais regionais de direitos humanos - cuja base legal encontra-se em tratados de direito público internacional (Slaughter, 1997; Fischer-Lescano, s/d). Esses teóricos assinalam também o caráter cada vez mais hard da legislação internacional sobre direitos huma- 
nos (o jus cogens), que invalida toda e qualquer lei que admita a tortura, o genocídio, o desaparecimento de pessoas, as execuções ilegais, os crimes contra a humanidade e atos do mesmo gênero ${ }^{30}$, alegando que já existem regras constitucionais de jurisdição, normas globais de recurso judicial, tribunais e legislação constitucional formal (normas relativas à formação legal de normas - tratados jurídicos obrigatórios até para os não-signatários) na arena política mundial. Certamente ninguém diz que a constituição política global está completa por causa do vergonhoso déficit democrático. Não há nenhum poder constituinte e representação política no plano mundial, e, portanto, existe carência de legitimidade democrática. O que antes se afirmava é que havia uma constituição política global, não uma constituição democrática.

Gostaria de chamar a atenção para os perigos dessa tese sobre o constitucionalismo societário. A idéia de que o direito globalizado medeia e institucionaliza a sociedade civil no subsistema político mundial, moderando a soberania do Estado através de mecanismos de efeito direto e outros, é importante. No entanto, é perigoso e apologético afirmar que já existe uma constituição global nesse terreno. Isso porque, dada a ausência do princípio de separação de poderes (no Conselho de Segurança das Nações Unidas, por exemplo) e a limitada jurisdição da Corte Internacional de Justiça, persistem grandes lacunas jurídicas, para não mencionar a falta de clareza sobre a condição de lei básica dos direitos humanos como hard law. Continuamos sem saber com certeza o que é regra de reconhecimento nesse domínio globalizado e que regras secundárias dizem respeito à mudança da lei básica. Tampouco existe consenso quanto aos parâmetros fundamentais do processo legislativo que produz regras de precedência. Tampouco existe consenso quanto aos parâmetros fundamentais do processo legislativo que gera o direito de preferência ou de preempção.

O perigo de afirmar que já existe uma constituição global em escala política mundial é o de fortalecer a tendência de invocar a cobertura da lei - pretextando um suposto "direito" à intervenção humanitária -, ou apelar para princípios de direitos humanos, para justificar duras intervenções em países mais fracos, sejam elas de natureza violenta ou não violenta, por parte de alianças de Estados ou de potências individuais somente interessadas em seus próprios objetivos. Em outras palavras, o discurso do constitucionalismo dá cobertura legal a ações carentes de princípios e incentiva o uso simbólico abusi- 
vo da idéia de direito constitucional. É esta a razão que me leva a insistir na necessidade de olhar com reservas essas alegações.

Não estou dizendo que a intervenção em nome da defesa de direitos humanos é sempre desnecessária ou ilegal, mas que ainda não temos condições de afirmar com clareza quais são as regras ou qual é a reflexão crítica sobre as regras nessas situações. Certo é que o discurso antecipa a importante tarefa de constitucionalização de vários domínios globalizados; é uma verité à faire [verdade a comprovar], e ainda não chegamos lá. Gostaria de concluir analisando esse problema.

\section{CONCLUSÃO}

Estou convencida de que a globalização da sociedade civil trouxe importantes êxitos no campo dos direitos humanos, incentivou a gênese de um direito mundial, estimulou a sensibilidade para problemas ecológicos e para o avanço da democratização de sociedades nacionais devido, em boa parte, ao efeito bumerangue mencionado acima. A sociedade civil continua a ter um importante papel no avanço da juridicidade da sociedade internacional. É possível falar na existência de uma grande quantidade de leis na esfera internacional e global, mas não ainda de constitucionalismo. Em certos aspectos, o papel dos atores da sociedade civil globalizada é maior aí do que no plano das sociedades nacionais, pois na esfera global não há uma sociedade política equivalente, nem órgãos representativos e responsabilizáveis empenhados na elaboração de decisões coletivamente obrigatórias, mas sujeitas à sanção eleitoral, como acontece nos Legislativos e Executivos nacionais. Portanto, partindo desse ponto de vista, os atores da sociedade civil têm mais o que fazer no domínio global do que na esfera nacional.

Contudo, é um erro considerar as organizações não-governamentais, associações locais e redes que povoam a sociedade civil transnacional como equivalentes funcionais das instituições representativas e da sociedade política (partidos, sindicatos) na esfera nacional em democracias constitucionais. A sociedade civil não consegue fiscalizar por conta própria as novas e poderosas instituições supranacionais ou subnacionais de governança. A verdade é que a própria sociedade civil precisa ser fiscalizada. Redes e associações civis podem ser muito excludentes, injustas, desiguais e antidemocráticas. Mais do que isso, organizações não governamentais ricas têm condições de incentivar o 
desenvolvimento de sociedades civis autônomas locais nos países em desenvolvimento ou de ocupar o lugar, junto com suas verbas, de iniciativas locais, contribuindo, assim, para enfraquecer, em vez de fortalecer, as ações conducentes à construção da democracia, da confiança horizontal e da solidariedade social. Em suma, os fiscalizadores devem ser fiscalizados.

O papel da sociedade civil em cada domínio globalizado, além disso, não é o de se colocar em lugar da sociedade política representativa faltante (o governo), porque a conseqüência seria sobrecarregar demais os atores da sociedade civil, cujo papel é o de exercer influência, não o poder ou tomar decisões coletivamente obrigatórias. Aí está o erro da noção de sociedade civil globalizada a que aludi na introdução deste artigo. Só que também não se pode restringir as funções desses atores à criação de normas (segundo o modelo da sociedade civil transnacional $)^{31}$. Em cada domínio globalizado os atores da sociedade civil têm, ao contrário, a tarefa, por assim dizer, adicional de ajudar a criar seus interlocutores, isto é, o equivalente funcional de uma sociedade política responsiva, e fazer pressão pela institucionalização da sociedade política e por mecanismos de cobrança de responsabilidade pública. Isso inclui a constitucionalização de cada domínio globalizado, no sentido de Hart, a fim de tornar representativos e responsabilizáveis aqueles que tomam decisões coletivamente vinculativas, além de fazer com que se abram à influência da sociedade civil. Em outras palavras, a constitucionalização da governança supranacional e a criação de instituições representativas e responsabilizáveis, inclusive a separação e o equilíbrio de poderes, ainda não foram consumadas, são tarefas por cumprir. Os defensores de uma constituição para a União Européia já compreenderam essa aspiração. E, somente se ela for alcançada, será possível falar na estrita observância da ordem jurídica e do fim do "déficit democrático" da governança supranacional.

A regulação da auto-regulação por parte de uma sociedade política representativa, responsiva, responsabilizável, que toma decisões públicas e coletivamente vinculativas, é indispensável para o futuro de uma democracia global. É preciso forjar uma sociedade política global e regional e faz-se necessário torná-la forte no âmbito nacional, mesmo enquanto a soberania dos Estados esteja sendo parcialmente desagregada e mesmo que os atores da sociedade civil logrem impor a aceitação de princípios de direitos humanos, a preocupação com as 
questões ecológicas e assuntos semelhantes a todos os atores políticos.

O processo político nas sociedades civis globalizadas, com suas novas formas de pluralidade, publicidade e privacidade, não pode mais ser analisado com os termos usados para sua antecessora, a sociedade civil nacional. A nova formação social é mais forte do que muitos Estados em vários aspectos. Poucos Estados (nem os Estados Unidos, provavelmente) podem fugir e resistir à pressão da mobilização internacional em torno das questões dos direitos humanos, da ecologia, do trabalho e da cultura. Isso porque os atores civis tem hoje condições de mobilizar Estados e organizações regionais por meio dos processos de comunicação e pelo exercício da pressão política. Isso quer dizer que na nova sociedade civil global a política de influência é complementada pela utilização de algumas formas de poder. A constitucionalização de regimes globais ajudaria a conferir-lhes legitimidade e legalidade.

Isso tem importância especial para a economia global. Nesse terreno, os atores da sociedade civil global, e mesmo regional, são muito mais fracos do que seus correspondentes nacionais. Como se sabe, a economia global é dominada por um consenso neoliberal e apesar das significativas críticas dos atores da sociedade civil, suas instituições, do FMI ao Banco Mundial, não têm sido muito sensíveis às demandas por justiça socioeconômica ou às reivindicações de participação nas deliberações daqueles que são afetados por tais decisões. Sem a institucionalização de uma sociedade política bastante inclusiva nos organismos públicos que tomam as decisões econômicas mundiais, atores das redes da sociedade civil e a "opinião pública mundial" não terão condições de influir ou ter controle nesse nível decisório.

Embora pareça irônico concluir desta forma um ensaio sobre a sociedade civil, eu diria que a principal tarefa de hoje é construir uma sociedade política responsável e responsabilizável nas instituições globais e reconstruir as sociedades políticas e os desenhos institucionais nacionais que parecem estar em crise (principalmente nos Estados Unidos), se quisermos assegurar uma relação saudável e eficiente entre a sociedade civil, os direitos humanos, o estado de direito, a democracia e a justiça social. 


\section{NOTAS}

1. Ver Cohen e Arato (1992); Arato (2000); Putnam (2000; 1993); Cohen (1999), para análises sobre o debate acerca do conceito de sociedade civil no último terço do século XX.

2. Estou parafraseando Habermas (2001:67).

3. Ver Jayasuriya (2001) sobre a natureza gerencial desse enfoque sobre a sociedade civil.

4. Ver Rosenau (1999), Hirst e Thompson (1996), Slaughter (1997), sobre as novas redes de organismos reguladores responsáveis pela criação de normas internacionais que fogem ao modelo das relações entre Estados nacionais. Ver, também, Jayasuriya (2001).

5. Rosenau (1999:38-51) cita as cidades globais, juntamente com a sociedade civil, como equivalentes funcionais do controle estatal. Não estamos ainda convencidos da propriedade dessa equivalência. Ainda não nos parece claro que seja possível realizar funções públicas e formas democráticas de participação e prestação de contas sem as devidas transformações da sociedade política.

6. Ver a crítica de Carl Schmitt sobre a retórica do humanitarismo e dos direitos humanos em Schmitt (1976; 2003).

7. Para uma análise da história desse conceito, ver Cohen e Arato (1992, cap. 1).

8. É claro que a liberdade de contrair matrimônio estava limitada aos heterossexuais, e a autonomia da pessoa dentro do casamento era prerrogativa do homem, na qualidade de chefe da família. Havia muitas restrições a relações maritais, e o sexo fora do casamento era condenado.

9. Sobre a distinção entre públicos civis e políticos, ver Cohen e Arato (1992). Acerca do conceito de públicos fortes e fracos, ver Fraser (1992). A distinção entre os conceitos de público civil fraco e público político forte deve ser entendida como um contínuo. Os públicos fracos são, relativamente falando, mais deliberativos e susceptíveis a poucas restrições no que toca às deliberações. Públicos decisórios fortes são mais restringidos, tanto qualitativa quanto quantitativamente (por exemplo, o prazo para a deliberação é mais curto). Um exemplo de público civil não institucionalizado, aberto a todo tipo de raciocínio e declarações, é um grupo de conscientização dentro de um movimento feminista. Um júri é um exemplo de público civil institucionalizado "forte" no sentido de que suas deliberações acarretam decisões politicamente vinculativas. Um parlamento é um público institucionalizado ainda mais forte, dado que legisla para toda a sociedade. Sobre uma outra forma de diferenciar as várias restrições impostas a diversos tipos de públicos, ver Rawls (1993:212-254).

10. Essa forma de conceituar a esfera pública evita conferir legitimidade a qualquer grupo ou instituição que proclame encarnar ou representar o público e se diga portador de autoridade para definir o que seja uma questão de interesse público. Ademais, não é possível decidir de modo definitivo por onde passa a linha divisória entre o público e o privado e quem deve ser incluído no domínio público.

11. Para uma reformulação do componente de privacidade na sociedade civil, ver Cohen (2002b). 
12. Para uma análise dos paradoxos da regulação que surgem no Estado regulatório, ver Sunstein e Arato (1998:26-36), Cohen (2002a:151-180). Para o conceito de "regulatory trilemma", ver Teubner (1993:239-285).

13. Direito reflexivo é uma nova forma de regulação que complementa, mas não substitui outra formas jurídicas. Decidir quando e onde um tipo de legislação ou modo de regulação é adequado é uma questão empírica. O direito reflexivo é uma forma de regulação da auto-regulação, não de privatização. Seu objetivo é dirigir a auto-regulação para fins públicos e incentivar a criação de procedimentos de resolução de conflitos e de tomada de decisões que facilitem a participação, a eqüidade e a influência dos interesses pertinentes. Ver Cohen (2002b, cap. 4).

14. Até que ponto esses arranjos foram transparentes e o grau de exclusão que promoveram é uma outra questão.

15. Isto também se aplica ao modelo antipolítico da sociedade civil desenvolvido no Ocidente. Ver a este respeito Arato (2000:1-81). Outro problema foi a necessidade de reconstruir uma sociedade política representativa e receptiva às contribuições da sociedade civil.

16. Cohen (1999:262-291), contém uma análise crítica dessas duas escolas que surgiram nos Estados Unidos nos anos 1900.

17. Ver nossa crítica de Parsons em Cohen e Arato (1992:118-142).

18. Para uma excelente discussão sobre esse assunto, ver Keck e Sikkink (1998:1-38).

19. Esses contatos são bastante efêmeros e instáveis. O argumento de Putnam provavelmente funciona melhor para esses tipos de "redes".

20. Para uma discussão sobre esses assuntos, ver Arquilla e Ronfeldt (2001).

21. Para uma excelente análise do conceito, ver Jaeger (s/d).

22. Para um diagrama veja Keck e Sikkink (1998:13).

23. Parafraseio Keck e Sikkink (1998:16). Esta parte do artigo se baseia nas excelentes análises de ambas.

24. Prova disso são os bons resultados obtidos na organização do movimento das mulheres em torno de questões relacionadas com a saúde, defesa contra a violência e a transgressão de direitos humanos (o estupro) e temas ligados ao desenvolvimento no âmbito mundial. Ver a este respeito Keck e Sikkink (1998:165-198).

25. Era esta a tendência antes dos acontecimentos de 11 de setembro de 2001.

26. Sobre o conceito de "constitucionalismo societário", ver Teubner (1996) e outros textos mais recentes.

27. Baseio-me em Rosenau (1999:28-57), para o conceito de governança.

28. Cito o termo cunhado por Gunther Teubner.

29. Não se trata de uma questão de eficácia da lei ou de disponibilidade de sanções, como geralmente se encara o assunto ao pôr em confronto as deficiências do direito internacional ou supranacional e a legislação do Estado nacional, mas de um problema de validade.

30. Cito o Artigo 53 da Convenção de Direitos Humanos de Viena.

31. O mesmo pode ser dito sobre o modelo gerencial: embora a inclusão em arenas deliberativas nas áreas econômicas seja uma importante aspiração para domar o capi- 
talismo globalizado, os atores da sociedade civil não se dedicam mais à atividade de obter lucros do que a de governar.

\section{REFERÊNCIAS BIBLIOGRÁFICAS}

ANDERSON, Perry. (1977), “The Antinomies of Antonio Gramsci”. New Left Review, no 100, pp. 5-78.

ARATO, Andrew. (2000), Civil Society, Constitution and Legitimacy. New York, Rowman and Littlefield Publishers.

ARQUILLA, John e RONFELDT, David. (eds). (2001), Networks and Netwars: The Future of Terror, Crime, and Militancy. The Rand Corporation, caps. 1, 7 e 10.

BLACK, Julia. (1997), Rules and Regulators. New York, Oxford University Press.

CALHOUN, Craig (org.). (1992), Habermas and the Public Sphere. Cambridge, MIT Press.

CHAMBERS, Simone. (2002), "A Critical Theory of Civil Society", in S. Chambers e W. Kymlicka (eds.), Alternative Conceptions of Civil Society. Princeton, Princeton University Press, p. 94.

COHEN, Jean L. (1999), “Does Voluntary Association Make Democracy Work?”, in N. J. Smelser e J. C. Alexander (eds.), Diversity and Its Discintents: Cultural Conflict and Common Ground in Contemporary American Society. Princeton, Princeton University Press.

(1999a), "Changing Paradigms of Citizenship and the Exclusiveness of the Demos". International Sociology, vol. 14, no 3, pp. 245-268.

(1999b), “Trust, Voluntary Association and Workable Democracy: The Contemporary American Discourse of Civil Society", in M. E. Warren, Democracy and Trust. Cambridge, Cambridge University Press.

_ (2002a), Regulating Intimacy: A New Legal Paradigm. Princeton, Princeton University Press.

_ (2002b) "The Debate over the Reflexive Paradigm", in Regulating Intimacy: A New Legal Paradigm. Princeton, NJ., Princeton University Press, pp. 151-180.

COHEN, Jean L. (no prelo), "The Self Institution of Society and Representation: Can the Circle Be Squared?". Thesis, nำ 11.

_ e ARATO, Andrew. (1992), Civil Society and Political Theory. Cambridge, Mass., MIT Press.

CUTLER, A. Claire. (2001), “Late Capitalism Merchant Rule”. Constellations, vol. 8 nº 4, pp. 480-502. 


\section{Jean L. Cohen}

DORF, Michael e SABEL, Charles. (1998), “A Constitution of Democratic Experimentalism". Columbia Law Review, vol. 96, nํ2, pp. 267-473.

EMIRBAYER, Mustafa e GOODWIN, Jeff. (1994), “Network Analysis, Culture and the Problem of Agency". American Journal of Sociology, vol. 99, no 6, pp. 1411-1454.

FALK, Richard. (2000), "Global Civil Society and the Democratic Prospect", in B. Holden (org.), Global Democracy: Key Debates. New York, Routledge.

FISCHER-LESCANO, Andreas. (s/d), Constitutional Rights - Constitutional Fights: Human Rights and the Global Legal System. Manuscrito.

FRASER, Nancy. (1992), "Rethinking the Public Sphere: A Contribution to the Critique of Actually Existing Democracy", in C. Calhoun (org.), Habermas and the Public Sphere. Cambridge, MIT Press.

e GORDON, Linda. (1994), "A Genealogy of Dependency: Tracing a Keyword of the U. S. Welfares State”. Signs, vol. 19, no 2, Winter, pp. 309-336.

GRAMSCI, Antonio. (1971), "State and Civil Society", in Selections from Prison Notebooks. Nova Yorque, International Publishers.

HABERMAS, Jürgen. (1989), The Structural Transformation of the Public Sphere. Cambridge, MIT Press.

(1996a), "Popular Sovereignty as Procedure", in Between Facts and Norms. Cambridge, MIT Press, pp. 462-490.

_ (1996b), Between Facts and Norms. Cambridge, MIT Press, pp. 82-131.

_ (2001), The Postnational Constellation. Cambridge, Mass, MIT Press.

HAUFLER, Virginia e PORTER, Tony (orgs.). (1999), Private Authority and International Affairs. New York, S.U.N.Y Press.

HELD, David. (1995), Democracy and the Global Order: From Modern State to Cosmopolitan Governance. Stanford, Stanford University Press.

HIRST, Paul e THOMPSON, Grahame. (1996), Globalization in Question: The International Economy and the Possibility of Governance. London, Polity.

JAEGER, Hans Martin. (s/d), World Opinion and the Transformation of International Governance. Tese de doutorado em andamento, Columbia University.

JAYASURIYA, Kanishka. (2001), “From Political to Economic Constitutionalism". Constellations, vol. $8, \mathrm{n}^{\mathrm{o}} 4$.

KALDOR, Mary. (1999), "Transnational Civil Society", in T. Donne e N. J. Wheeler (orgs.), Human Rights in Global Politics. Cambridge, Cambridge University Press.

KECK, Margaret e SIKKINK, Kathryn. (1998), Activists Beyond Boarders: Advocay Networks in International Politics. Ithaca, Cornell University Press.

KRASNER, Steven. (1999), Sovereignty: Organized Hypocrisy. Princeton, Princeton University Press.

LIEBERMAN, Robert. (1998), Shifting the Colour Line: Race and the American Welfare State. Cambridge/Mass, Harward University Press. 


\section{Sociedade Civil e Globalização: Repensando Categorias}

LINKLATER, Andrew. (1999), “The Evolving Spheres of International Justice”. International Affairs, vol. 75, no 3, pp. 473-482.

MANIN, Bernard. (1997), The Principles of Representative Government. Cambridge, Cambridge University Press.

MELUCCI, Alberto. (1980), "The New Social Movements: A Theoretical Approach". Social Science Information, $\mathrm{n}^{\mathrm{O}} 19$.

(1985), "The Symbolic Challenge of Contemporary Movements". Social Research, vol. 52, no 4 , pp. 798-816.

PASHA, Mustapha K. e BLANEY, David L. (1998), “Elusive Paradise: The Promise and Peril of Global Civil Society", Alternatives, vol. 23, nº 4, pp. 417-450.

PUTNAM, Robert. (1993), Making Democracy Work. Princeton, NJ, Princeton University Press.

(2000), Bowling Alone: The Collapse and Revival of American Community. New York, Simon \& Schuster.

RAWLS, John. (1993), “The Idea of Public Reason”, in Political Liberalism. Massachusetts, Cambridge, Harvard University Press, pp. 212-254.

ROSENAU, James N. (1997), Along the Domestic/Foreign Frontier: Exploring Governance in a Turbulent World. Cambridge, Cambridge University Press.

_ (1999), "Governance and Democracy in a Globalized World”, in D. Archibugi, D. Held e M. Köhler (eds.). Re-imagining Political Community: Studies in Cosmopolitan Democracy. Stanford, Stanford University Press, pp. 28-58.

ROTHSTEIN, Bo. (1998), Social Capital in the Social Democratic State: The Swedish Model and Civil Society. Trabalho apresentado na reunião da APSA. Manuscrito.

SASSEN, Saskia. (1996), Losing Control? Sovereignty and Age of Globalization. New York, Columbia University Press.

SCHMITT, Carl. (1976), The Concept of the Politics. New Jersey, Rutgers University Press.

_ (2003), Nomos der Erde. New York, Telos Press.

SIRIANNI, Carmem e FRIEDLAND, Lewis. (2001), Civic Innovation in America. Berkeley, University of California Press.

SLAUGHTER, Anne Marie. (1997), “The Real New World”. Foreign Affairs, vol. 76, nº 5.

SORENSEN, George. (1999), "Sovereignty: Change and Continuity in a Fundamental Institution", in R Jackson (ed.), Sovereignty at the Millenium. Massachusetts, Blackwell.

STRANGE, Susan. (1996), The Retreat of the State: The Diffusion of Power in the World Economy. Cambridge, Cambridge University Press.

SUNSTEIN, Cass e ARATO, Andrew. (1998), “Procedural Law and Civil Society: Interpreting the Radical Democratic Paradigm", in M. Rosenfeld e A. Arato (orgs.), Habermas on Law and Democracy: Critical Exchanges. Berkeley, University of California Press, pp. 26-36. 
Jean L. Cohen

TEUBNER, Gunther. (1993), "Substantive and Reflexive Elements in Modern Law". Law and Society Review, vol. 17, no 2, pp. 239-285.

__ (org.). (1996), Global Law Without a State. London, Dartmouth Publishing Co.

THOMA, Daniel. (2001), The Helsinki Effect: International Norms, Human Rights and the Demise of Communism. Princeton, Princeton University Press.

TOURAINE, Alain. (1981), The Voice and the Eye. New York, Cambridge University Press.

WHITE, Harrison. (1995a), "Where do Languages Come From?", Primeira parte, pre-print series, Lazarfeld Center for Special Sciences, Columbia University.

(1995b). "Network Switchings and Bayesian Forks". Social Research, vol. 62, pp. $1035-1063$.

\begin{abstract}
Civil Society and Globalization: Rethinking the Categories

The discourse of civil society has gone global. Once again theorists of democracy are placing their bets on civil society to generate solidarity, publicity, civicness, awareness of new forms of injustice, and democracy vis-à-vis the new world order. Yet too many analysts are naïvely optimistic or ideological about global civil society's democratizing role. In order to visualize the proper role of civil society in the global context, careful systematic analysis is needed concerning the ways in which globalization has transformed the key parameters of civil society and how such changes recursively affect how civil society impacts national, regional, transnational, and supranational bodies. There can be no vital democracy without civil society, but civil society cannot replace constitutional democracy or the rule of law at any level of government.
\end{abstract}

Key words: civil society; globalization; networks 
RÉSUMÉ

Société Civile et Mondialisation: Des Réflexions Nouvelles sur les

Catégories

Le discours de la société civile est d'habitude mondialisé. Une fois de plus, les théoriciens de la démocratie situent leurs enjeux dans la société civile pour engendrer solidarité, citoyenneté, droits civils, rejet de nouvelles formes d'injustice, et démocratie face au nouvel ordre mondial. Mais trop d'analystes sont naïvement optimistes ou marqués par l'idéologie à propos du rôle démocratique de la société civile globale. Afin d'examiner le rôle exact de cette société dans le cadre mondialisé, il faut effectuer une analyse soignée et systématique des façons selon lesquelles la mondialisation a transformé les indicateurs de la société civile et comment, par conséquent, ces transformations se répercutent sur la société civile dans le domaine national, régional, transnational et supranational. Il n'y a pas de démocratie vivante sans société civile, mais la société civile ne peut remplacer, à aucun niveau de l'exercice de gouverner, la démocratie constitutionnelle ou la norme de la loi.

Mots-clé: société civile; mondialisation; réseau 